\title{
傾斜機能圧電アクチュエータの開発
}

河 合高志・宮 崎俊一

(横河電機 (株) 研究開発 3 部第 2 研究室, 180 東京都武蔵野市中町 2-9-32)

\section{Development of a Piezo-Ceramic Actuator with Functionally Gradient Material}

\author{
Takashi KAWAI and Shun-ichi MIYAZAKI
}

(Section 2, Corporate R \& D Department III, Yokogawa Electric Corp., 2-9-32, Naka-cho, Musashino-shi, Tokyo

\begin{abstract}
A new type of piezoelectric actuator was developed. This piezoelectric actuator consists of three layers : a piezoelectric ceramic layer, a middle layer whose composition changes gradually, and another ceramics layer with a high dielectric constant. This type of material is called Functionally Gradient Material (FGM). Two green sheets made from two different materials were laminated and sintered monolithically. The compositions of these two different ceramics were selected from the system $\mathrm{Pb}\left(\mathrm{Ni}_{1 / 3} \mathrm{Nb}_{2} /_{3}\right) \mathrm{O}_{3}-\mathrm{PbZrO}_{3}-\mathrm{PbTiO}_{3}$. The bending displacement is about $60 \mathrm{um}$, at $100 \mathrm{~V}$ applied at room temperature. The size of the plate $(L \times W \times t)$ is $25 \times 5 \times 0.65 \mathrm{~mm}^{3}$. An attempt was made to prepare a 3-dimensional FGM piezoelectric plate using a dispenser with a computer controlling the XY-stage. This equipment can change the distribution of the composition along the plane and across the thickness direction. An FGM piezoelectric plate that has a periodic structure ( $A$ on $B$ vice versa alternating side by side repeatedly) is made by this equipment.

[Received March 14, 1990; Accepted April 13, 1990]
\end{abstract}

Key-words : Functionally Gradient Material (FGM), Piezoelectric actuator, PZT, Doctor blade, Dispenser

\section{1. 緒言}

ユニモルフ型やバイモルフ型の圧電アクチュエータ は, 圧電セラミックスとシムと呼ばれる薄い金属板を, 接着剈で貼り合わせた構造のアクチュエータで, 圧電ス ピーカーや微小変位素子として，広く応用されている。 しかし，接着凨を使用しているために，低温での接着剤 の割れや, 高温でのクリープや剥離, 寿命の点で, 高信 頼性を要求される計測制御機器に応用するには問題が あった。

この問題の解決策の一つとして, 傾斜機能材料 (Functionally Gradient Material 以下, FGM と略記 する）と呼ばれる材料を使用する方法が考えられる。こ の材料は, 従来の均一な材料と異なり，材料の中に積極 的に制御された不均一性を導入することにより，材料の 性能の向上や，新しい機能の発現をめざした，新しい夕 イプの材料である11。

著者らは, 圧電体と高誘電率材料を組み合わせること により，厚み方向に組成が傾斜した，接着剤を使用しな い，ユニモルフ型の屈曲変位素子を，プレス成形と焼結 により作製した21,3).この素子では接着剂を用いないた めに, 耐熱性や剥離の点で, 従来のものより信頼性が高 W.

しかし，プレス成形では量産性が低く，また，厚さの 制御性や平坦度にも問題があるために, ドクターブレー
ド法による作製を試みた。

またここ過程において，フィルムキャスティングし たスラリーが完全に乾燥しないうちに, 組成の異なるス ラリーをこの上に塗布すると，接合性が良好な成形体を 作製できる点に着目し，面方向及び厚み方向に組成を変 化させる方法を開発し, 組成が周期的に変化するシート 及びパイプの作製を試みた。

一次元的な傾斜機能材料組成制御では，応用範囲が限 られるが，面方向の組成分布の制御ができれば，圧電材 料の特性を目的に合わせて設計できる可能性が開ける。

\section{2. 実験方法}

\section{1 材料の選択}

屈曲変位を発生する FGM アクチュエー夕を作製す るための傾斜機能材料の組み合わせとして, 以下の三つ が考えられる4),5).

（1）金属・圧電セラミックス,

（2）導電性セラミックス・圧電性セラミックス,

（３） 2 種の圧電性セラミックス.

この中で初めの二つは, 焼結特性や熱膨張率の差が大 きいことと, 構造上傾斜組成層の厚さを厚くできないこ とから，3番目の組み合わせを選んだ。

変位が大きいアクチュエータを実現するためには，圧 電定数が高く, 誘電率が小さい材料と, 圧電定数が低く, 
誘電率が大きい材料を組み合わせ，焼結特性がよく似た 系を選ぶ必要がある。

二つの材料が積層され，これに電圧を印加した場合， 電圧は各々の材料の比誘電率の逆数に比例して, それぞ れの材料に分配される. 変位に寄与するのは圧電材料に 加えられた電圧であるため, 高誘電率材料に分配される 電圧は，できるだけ少ない方が望ましい，しかし，高誘 電率材料はシムの役割を持つため, 厚さをゼロにはでき ず，ある一定の厚さが必要である. したがって, 高誘電 率材料側に分配される電圧をできるだけ小さくするため には，誘電率ができるだけ大きい方が望ましい。

最大の変位を与える二つの材料の厚さの比は (1) 式 で与えられる。

$$
\frac{h_{\mathrm{b}}}{h_{\mathrm{a}}}=\left(\frac{Y_{\mathrm{a}} \varepsilon_{\mathrm{b}}}{Y_{\mathrm{b}} \varepsilon_{\mathrm{a}}}\right)^{1 / 2}
$$

ここで, $h_{\mathrm{a}}, h_{\mathrm{b}}$ は圧電材料と高誘電率材料の厚さ， $Y_{\mathrm{a}}$ $Y_{\mathrm{b}}$ はそれぞれの材料のヤング率， $\varepsilon_{\mathrm{a}}, \varepsilon_{\mathrm{b}}$ は比誘電率で ある。

$\mathrm{PZT}-\mathrm{NiNb}$ 系の 3 成分系の圧電セラミックスは, 比 較的低温で緻密な組成が得られ, 圧電性が高い組成及び 比誘電率が高い組成が存在する ${ }^{6)}$.

本実験では圧電材料之高誘電率材料として, それぞれ 以下のものを使用した。

$\mathrm{Pb}\left(\mathrm{Ni}_{1 / 3} \mathrm{Nb}_{2 / 3}\right)_{0.5}\left(\mathrm{Ti}_{0.7} \mathrm{Zr}_{0.3}\right)_{0.5} \mathrm{O}_{3}$ 圧電材料

$\mathrm{Pb}\left(\mathrm{Ni}_{1 / 3} \mathrm{Nb}_{2 / 3}\right)_{0.7}\left(\mathrm{Ti}_{0.7} \mathrm{Zr}_{0.3}\right)_{0.3} \mathrm{O}_{3}$ 高誘電率材料 (B)

図 1 に二つの材料の比誘電率の温度依存性を示す。室 温付近では二つの材料が, 要求される条件を満たしてい ることがわかる。

\section{2 スラリーの調製}

構成元素の酸化物を所定のモル比に科量し，ボールミ ルで粉砕混合後, $900^{\circ} \mathrm{C}$ で仮焼し, これを再度繰り返し て合成した。

合成した原料に純水, EDTA 系の錯化剂, 消泡剂, グリセリンを加え，24 時間ボールミルで粉砕した後，

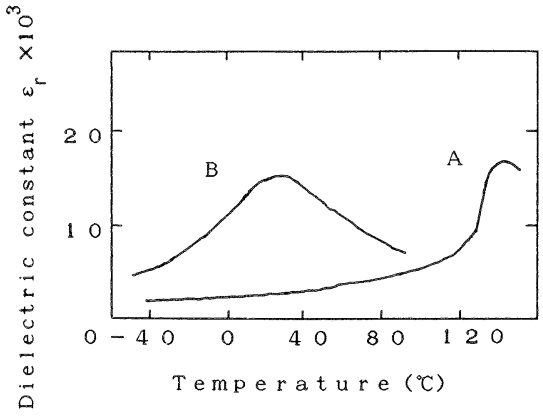

Fig.1. Temperature dependence of dielectric constant.

$\mathrm{A}: \mathrm{Pb}\left(\mathrm{Ni}_{1 / 3} \mathrm{Nb}_{2 / 3}\right)_{0.5}\left(\mathrm{Ti}_{0.7} \mathrm{Zr}_{0.3}\right)_{0.5} \mathrm{O}_{3}$, $\mathrm{B}: \mathrm{Pb}\left(\mathrm{Ni}_{1 / 3} \mathrm{Nb}_{2 / 3}\right)_{0.7}\left(\mathrm{Ti}_{0.7} \mathrm{Zr}_{0.3}\right)_{0.3} \mathrm{O}_{3}$
水溶性ポリアクリル酸系のバインダーを固形分に換算し て $8.5 \mathrm{w} \%$ 添加し, 更に 2 時間ボールミルを用いて混合 した。

バインダーと原料中の未反応の多価金属イオンが反応 すると，スラリーがゲル化するため，仮焼を二回，比較 的高い温度でおこない, 更に, EDTA 系の錯化剂で金 属イオンをマスクした後にバインダーを加え，未反応多 価イオンが極力少なくなるように留意した。

スラリーを，真空容器中でかくはんしながら，脱泡し て，2000 P 程度の粘度になるまで溶媒を蒸発させた。

スラリーの最適な粘度は作製するシートの厚さによっ て異なり, $200 \mu \mathrm{m}$ 程度の場合には $1000 \mathrm{P}$ 程度, $1 \mathrm{~mm}$ 以上では 1800 2000 程度が適当である.

\section{3 ドクターブレード法によるシート成形と積層}

以下に述べる三つの方法でシートを成形し, 積層した。

(a) 各々のシートを独立にドクターブレード法で成 形し，大気中で圧着する.

(b) 各々のシートを独立にドクターブレード法で成 形し，真空中で圧着する(図 2(a))。

(c) 第一のスラリーをドクターブレード法で成形し, シートの表面が完全に乾燥しないうちに，この上に第二 のスラリーをドクターブレード法で塗布して, 成形と積 層を同時に行う（図2(b))。

(a) の方法ではシートの接着強度が弱く，また，層間 に閉じこめられた空気が，焼成時に膨張するために剝離 やクラックが発生する。

(b)，(c) では良好な接合が得られた。特に（c）では 界面での二つのスラリーが混ざり合うため, 焼成の前に 傾斜組成層を形成することができる。

最大の変位を得るために, 層の厚さの比を（1）式よ り計算される值, $h_{\mathrm{a}} / h_{\mathrm{b}}=2 / 3$ 程度になるように調整し た。

\section{4 面方向の組成分布の制御}

前述の (c) の方法で, フィルムキャスティングした スラリーが完全に乾燥しないうちに，組成の異なるスラ リーをこの上に塗布すると, 接合性が良好な成形体が得 られる点に着目し，面方向及び厚み方向に組成を変化さ せたシートの成形を試みた。

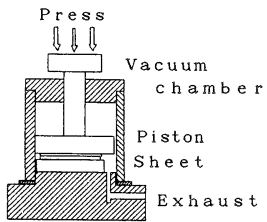

(a)

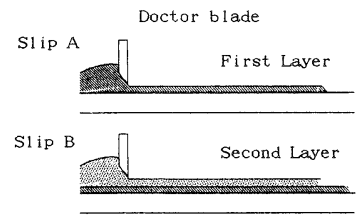

(b)
Fig. 2. Lamination method.

(a) Vacuum pressing,

(b) Double layer doctor blade 


\subsection{1 装置の構成}

図3, 図4に示すよjに，ディスペンサーを用いて， 平面上や円柱上にノズルからスラリーを押し出して塗布 し，積層する。

この方法は他の三つの方法と異なり, 面方向の組成を $0.7 \mathrm{~mm}$ 程度の位置分解能で変化させることができるこ 亡が特長である。

装置はディスペンサーよ $X Y$ ステージと、こ机を制 御するためのコンピュータで構成され，X方向に往復 するたびに， $Y$ 方向にわずかに進む $X Y$ ステージの上 に載せられたPETフィルムの上に，ディスペンサーの ノズルから押し出されたスラリーを塗布することによ り，シートが形成される.

ディスペンサーのカートリッジを交換しながら，2種 のスラリーを所定の幅に交互にフィルム上に塗布し, 周 期的に面方向に組成を変化させたシートを成形する。第 一層が完全に乾燥しないうちに第二層目を同様に塗布す る.

この系の材料の場合，最大の变位を与える層の厚さの 比は $h_{\mathrm{a}} / h_{\mathrm{b}}=2 / 3$ 程度であるが, 現在の装置では厚さの 制御が不完全なため場所に上り厚さの比が分布してい 万。

\section{4 .2 作製条件}

使用したノズルの内径は $0.8 \mathrm{~mm} \phi$, フィルムとノズ

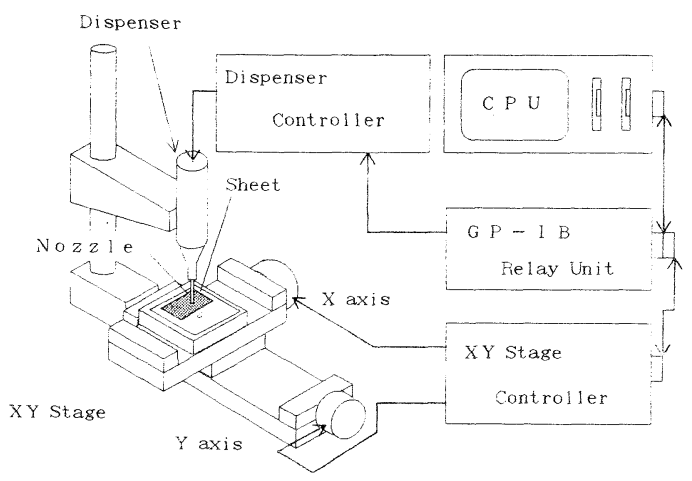

Fig. 3. FGM film casting system.

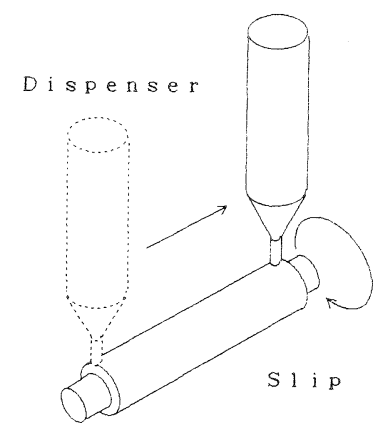

Metal axis

Fig. 4. FGM pipe forming method.
ルのギャップは $0.5 \mathrm{~mm}$ ，ステージの送り速度は 2 $\mathrm{mm} / \mathrm{s}$ である。 $Y$ 方向の一回の移動量は $0.5 \mathrm{~mm}$ で, ス ラリーは重なり合いながら, フィルム上に塗布さ机, 矩 形のパターンを描画する。

また，パイプを形成する場合には，金属の軸を回転さ せながら, 軸の表面にスラリーを塗布し, 乾燥した後に 軸を抜き取る。

作製したシートは，フィルムや軸に接触していた面は 平滑であるが，表面はノズルの軌跡に対応したわずかな 品凸が見られる。また二つの組成の境界面では, 乾燥収 縮量の差により段差が生じる。

图 5 に周期的に組成をステップ状に変化させて成形し たシート及びパイプの構造を示す。

\section{5 焼成}

焼成条件を図 6 に示す。 $500^{\circ} \mathrm{C}$ までは真空中で脱脂を 行い, その後は酸素雾囲気中で焼成する。焼成温度は $1180^{\circ} \mathrm{C}$ ，保持時間は $5 \mathrm{~h}$ である。

サンプルは，ふたつきの箱型アルミナセッターに人れ て焼成した。鉛の蒸発を防止するために，七ッタ一の中 に原料の粉末を充填した。

空気中で脱脂を行うと, 昇温速度を十分遅くしても発 火し，焼成体にクラックが発生する。PZT-NiNb 系の 材料が，ポリアクリル酸系のバインダーに対して。酸化 触媒作用があるのではないかよ考えられる。

層の压電アクチュエータは，変位特性を測定するた めに常温で $1000 \mathrm{~V}$ ⿸ $30 \mathrm{~min} \in \mathrm{E}$ 加して分極処理をおこ なった。 (a)

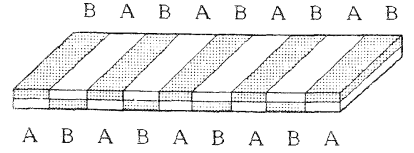

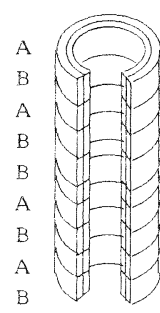

(b)
Fig. 5. Illustration of FGM plate and pipe structure. (a) FGM plate, (b) FGM pipe

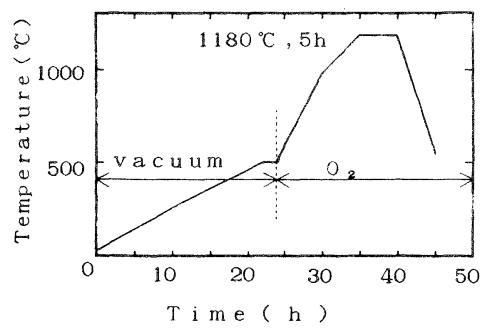

Fig. 6. Sintering time chart. 


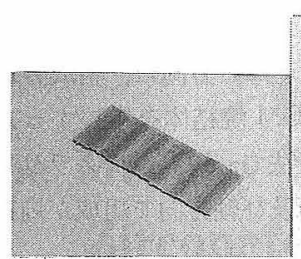

(a)

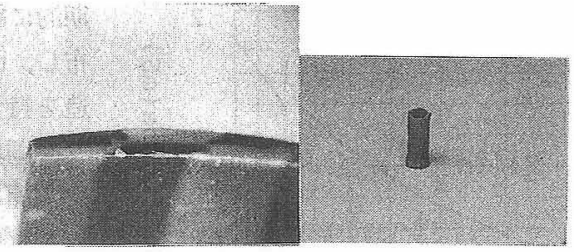

(b)

(c)

Fig. 7. Photograph of two examples of sintering.

(a) FGM plate,

(b) Cross section of the FGM plate,

(c) FGM pipe

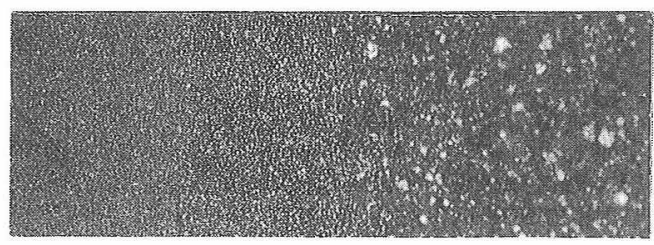

A

$\uparrow$

B

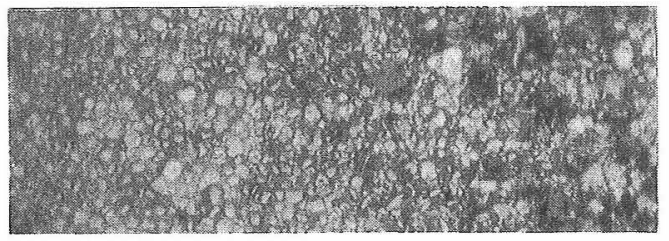

$10 \mu \mathrm{m}$

Fig. 8. Photograph of interface.

図7（a）に面方向に組成を制御した焼結体の写真を， 図7 (b) にその断面を示す。白い部分が王電材料, 黒 い部分が高誘電率材料である。図７（c) は, 組成が内側 之表面で異なっているパイプである.

焼成したサンプルの両面に銀ペーストを塗布し， $650^{\circ} \mathrm{C}$ で焼き付けて電極を形成した。

\section{1 界面の状態}

\section{3. 結果と考察}

図 8 に一つの材料の界面の光学顕微鏡写真を示す，明 瞭な界面やクラックは存在せず,一体焼成されているの がわかる、組織は緻密であり，大きい気孔はほとんど見 られない，真空中で脱脂し，酸素中で焼成した効果が現 れたもの上考えられる。

\section{2 変位特性の測定}

二層構造の分極処理した圧電アクチュエータについ て, サンプルの片側を固定し, 直流電圧を印加して自由 端の変位を測定した，変位特性は，サンプルの長さで規 格化すると，原料粉末を金型の中に積層して，プレス成 形した場合とほぼ同等であった。電圧-変位特性を図 9 に示す。特性の差が成形法によるものかどうかは不明で

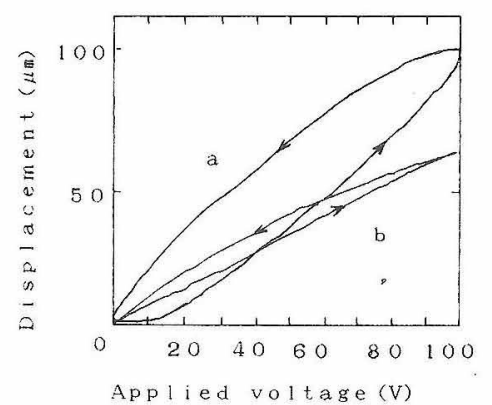

Fig. 9. Displacement characteristic of an FGM actuator.

(a) Powder pressing $40 \times 20 \times 0.6 \mathrm{~mm}^{3}$,

(b) Doctor blade $25 \times 5 \times 0.65 \mathrm{~mm}^{3}$

ある。

\section{3 振動子としての特性}

今回試作した単純な一層構造のサンプルについて, 共 振特性をインピーダンスアナライザーで観测した，通常 の圧電材料の炍では，洏面に電極を付けた場合には屈曲 振動は励起されにくい，これに対して試作したサンプル は、電圧により反りを牛しるため屈曲波が励起される.

板の脣曲振動の基本モ一ド (雨端自由) の共振周波数 $f_{\mathrm{i}}$ は近似的に(2) 式で与えられるゔ.

$$
f_{\mathrm{i}}=\frac{m_{\mathrm{i}}{ }^{2}}{4 \pi \sqrt{3}} \cdot \frac{t}{L^{2}} \cdot \sqrt{\frac{E}{\rho}}
$$

ここで，Eは材料のヤング率， $\rho$ は密度， $L$ と $を$ は板 の咓さと厚さである， $m_{\mathrm{i}}$ は振動モードによって決まる 定数で, 基本モードの場合は $m=4.69$ となる.

計算より求めた值は $1.47 \mathrm{kHz}$, 実测值は $1.49 \mathrm{kHz}$ 上 なりほば一致する。三次の高調波と思われる共振が 7.9 $\mathrm{kHz}$ に現れている。 サンプルのアドミッタンス及び位 相の周波数依存性を図 10 に示す.

この結果からわかるように，圧電材料を FGM 化す ることにより，特定のモードを選択的に励起することが できる.眓 7 に示したような，周期的な構造を導入する ことにより，圧電素子の特性を比較的自由に設計するこ とが可能となる，高次のモードの振動が励振される振動 


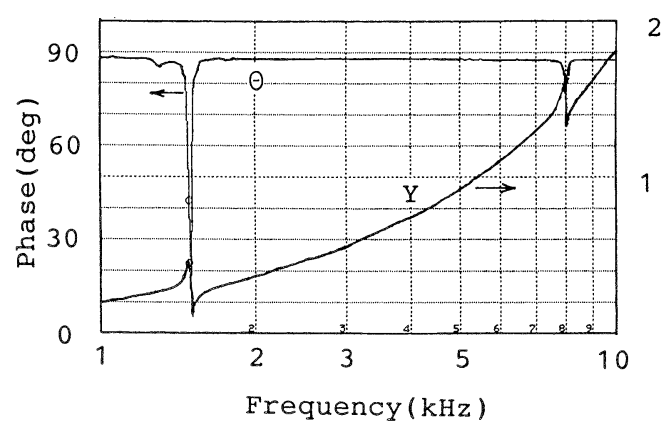

Fig. 10. Resonance frequency of an FGM actuator. The 1st mode is observed at $1.5 \mathrm{kHz}$ and the $3 \mathrm{rd}$ mode is observed at $7.9 \mathrm{kHz}$.

子, フィルター, 温度依存性が異なる圧電材料を複合す ることによる動作温度範囲の拡大，屈曲波を利用した進 行波型のアクチュエータ等に応用が可能と考えられる.

\section{4. まとめ}

圧電性が大きく, 誘電率が小さい材料 $(\mathrm{A})$ と, 圧電 性がほとんどなく，誘電率が大きい材料 (B) をドクター ブレード法で積層して，一体焼成した傾斜組成圧電セラ ミックスを作製し，電圧を印加することにより，従来の ユニモルフ型アクチュエータと同様の屈曲変位が発生す ることを確認した。

上記の材料のスラリーをディスペンサーを用いて，周
期的に組成をステップ状に変化させて，フィルム上に塗 布し，面方向と厚み方向に，組成分布を制御した周期構 造を持つ，FGM 焼結体を作製する方法を開発した。ま た，同様の方法で，円筒上にスラリーを塗布し，パイプ の内面と表面及び軸方向で組成が周期的に変化したパイ プを試作した。

この方法により，圧電材料の特性を目的に合わせて設 計することが可能になった。 圧電アクチュエータ, 超音 波振動子の温度依存性の改善や, 超音波モータ一等に応 用が可能と考えられる。

(1990 年 5 月日本セラミックス協会年会発表)

\section{文献}

1）昭和 61 年度科学技術振興調整費「複素化による機能発現 と熱応力緩和のための基盤技術に関する調査報告書」, 三 菱総合研究所 (1987).

2）田中江里子，宮崎俊一，河合高志，日本セラミックス協 会年会予稿集, 2 A 46 (1989).

3）河合高志，七ラミックス，24，975-79（1989).

4) 内野研二, 吉崎未来彦, 笠井潔, 山村 博, 坂井直道, 朝倉博史，窯協，95，722-25（1987）。

5）内野研二，（株）日本工業技術セン夕一編，“圧電／電歪 アクチュエータ”, 森北出版 (1986) p. 87.

6) 中 重治, 早川 茂,ファインセラミックステクノロジ一 シリーズ 3 「電子材料セラミックス」, オーム社 (1986) p. 42.

7）電子材料工業会監修，「圧電セラミックスとその応用」, 電波新聞社 (1974) p. 255. 